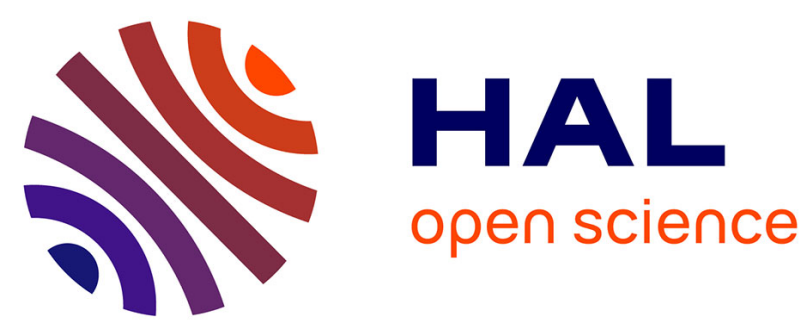

\title{
Spatial Patterns of Storm-Induced Landslides and Their Relation to Rainfall Anomaly Maps
}

Odin Marc, Marielle Gosset, Hitoshi Saito, Taro Uchida, Jean-Philippe Malet

\section{To cite this version:}

Odin Marc, Marielle Gosset, Hitoshi Saito, Taro Uchida, Jean-Philippe Malet. Spatial Patterns of Storm-Induced Landslides and Their Relation to Rainfall Anomaly Maps. Geophysical Research Letters, 2019, 46 (20), pp.11167-11177. 10.1029/2019GL083173 . hal-03517587

\section{HAL Id: hal-03517587 \\ https://cnrs.hal.science/hal-03517587}

Submitted on 8 Jan 2022

HAL is a multi-disciplinary open access archive for the deposit and dissemination of scientific research documents, whether they are published or not. The documents may come from teaching and research institutions in France or abroad, or from public or private research centers.
L'archive ouverte pluridisciplinaire HAL, est destinée au dépôt et à la diffusion de documents scientifiques de niveau recherche, publiés ou non, émanant des établissements d'enseignement et de recherche français ou étrangers, des laboratoires publics ou privés.

$$
\text { Copyright }
$$




\section{Geophysical Research Letters}

\author{
RESEARCH LETTER \\ 10.1029/2019GL083173 \\ Key Points: \\ - Patterns of storm-induced landslides \\ tracks the rainfall anomaly (relative \\ to a 10-year-return rainfall) better \\ than absolute rainfall \\ - Quantitative prediction of the spatial \\ pattern of storm-induced landsliding \\ is primarily achieved with slope and \\ rainfall anomaly maps \\ - Rock types with different \\ hydrological properties may \\ modulate the temporal scale over \\ which rainfall accumulation cause \\ landsliding
}

Supporting Information:

- Supporting Information S1

Correspondence to:

O. Marc,

odin.marc@erdw.ethz.ch

Citation:

Marc, O., Gosset, M., Saito, H., Uchida, T., \& Malet, J.-P. (2019). Spatial patterns of storm-induced landslides and their relation to rainfall anomaly maps. Geophysical Research Letters, 46, 11,167-11,177. https://doi.org/ 10.1029/2019GL083173

Received 4 APR 2019 Accepted 24 SEP 2019

Accepted article online 10 OCT 2019

Published online 28 OCT 2019

(C)2019. American Geophysical Union. All Rights Reserved.

\section{Spatial Patterns of Storm-Induced Landslides and Their Relation to Rainfall Anomaly Maps}

\author{
Odin Marc $^{1,2}$ (D) Marielle Gosset ${ }^{3}$, Hitoshi Saito ${ }^{4}$, Taro Uchida ${ }^{5,6}$, and Jean-Philippe Malet ${ }^{1}$ iD \\ ${ }^{1}$ École et Observatoire des Sciences de la Terre, Institut de Physique du Globe de Strasbourg, Centre National de la \\ Recherche Scientifique UMR 7516, University of Strasbourg, Strasbourg Cedex, France, ${ }^{2}$ Geological Institute, ETH Swiss \\ Federal Institute of Technology Zurich, Zurich, Switzerland, ${ }^{3}$ IRD/Géosciences Environnement Toulouse, Toulouse, \\ France, ${ }^{4}$ College of Economics, Kanto Gakuin University, Kanagawa, Japan, ${ }^{5}$ National Institute for Land and \\ Infrastructure Management, Tsukuba, Japan, ${ }^{6}$ Graduate School of Life and Environmental Sciences, University of \\ Tsukuba, Tsukuba, Japan
}

Abstract Storm-induced landslides are a common hazard, but the link between their spatial pattern and rainfall properties is poorly understood, mostly because hillslope stability is modulated by under-constrained, spatially variable topographic, hydrological, and mechanical properties. Here, we use a long-term rainfall data set from the Japanese radar network to discuss why the landslide pattern caused by a major typhoon poorly correlates with the event rainfall but agrees with the event rainfall normalized by the 10-year return period rainfall amount, that is, a rainfall anomaly. This may be explained if the variability in hillslope properties has coevolved with the recent climate and can be accounted for with such normalization. Further, rock types seem to respond to rainfall anomalies at various timescales, favoring specific landslide geometries, and suggesting various hydrological properties in these zones. The computation of rainfall anomalies for multiple timescales may pave the way toward operational landslide forecasts in case of large storms.

Plain Language Summary Landslides caused by heavy rainfall frequently cause substantial loss of life and property. However, the location of landslides across a landscape depends on both the rainfall amount and various local properties of the landscape (e.g., soil thickness and strength) that are difficult to measure. Here, we use 26 years of weather-radar measurements to show that the landslides caused by a large typhoon in Japan are poorly explained by the rainfall amount during the typhoon but much better by the rainfall anomaly, which is the amount of rainfall normalized by the rainfall amount occurring during extreme rainfall. We also find that landsliding seems driven by short, intense bursts of rainfall in regions underlain by some rock types while elsewhere rainfall accumulated over 2 days matters most. To replace total rainfall by rainfall anomaly and to consider rainfall accumulated over various time periods may fundamentally change landslide susceptibility scenarios and may allow quantitative forecasts of landslide patterns caused by large storms, based on weather forecasts and rainfall archives.

\section{Introduction}

Landsliding is an important natural hazard driven mainly by heavy rainfall and shallow earthquakes (Keefer, 2002; Keefer \& Larsen, 2007). For a given landslide, slope stability depends on numerous in situ properties, such as the local topography, rock/soil mass strengths, hydrologic properties, and vegetation cover (Iverson, 2000; Terzaghi, 1943), most of them poorly constrained and highly variable spatially, limiting the predictive skills of physical models (Keefer \& Larsen, 2007; Strauch et al., 2018). However, at the catchment scale, the variability of the in situ conditions and the associated probability of landsliding may be averaged, damping the effects of second-order controls and revealing first-order controls. For example, the spatial pattern of earthquake-induced landsliding has been shown to be proportional, above a threshold, to the magnitude of ground shaking and to its decay away from the seismic source (Meunier et al., 2007 and Meunier et al., 2013; Yuan et al., 2013). Although this regional scaling is simplified, including a reduced number of physical parameters, it allowed for the derivation of relationships for the total landslide volume or the region affected by landsliding (Marc, Hovius, Meunier, Gorum, et al., 2016, Marc et al., 2017), helping to understand the erosional impacts of earthquakes in different settings (Marc, Hovius, \& Meunier, 2016 and Marc et al., 2019; Li et al., 2017). It also bears important implications in terms of hazard zonation and scenarios on typhoon landslide and landscape evolution with climate accepted. 
In contrast, for rainfall-induced landslides, we still lack constraints on how the rainfall and its hydrological consequences are coupled to widespread landsliding. Many studies have focused on constraining the critical meteorological (trigger; e.g., intensity and duration) and more recently hydrological (cause) conditions (e.g., intensity and antecedent soil moisture) for the occurrence of landslides (e.g., Bogaard \& Greco, 2018; Caine, 1980; Guzzetti et al., 2008; Osanai et al., 2010; Wilson \& Wieczorek, 1995), but very few have quantified the spatial consistency between rainfall and landsliding beyond this threshold. A few studies quantified the amount of landsliding caused by successive storms in a given area and its relation to rainfall metrics (Chen et al., 2013; Reid, 1998) but did not analyze systematically the landslide pattern and its relations with the rainfall field. Based on eight landslide inventories associated with well-identified storm events and limited rainfall information, a power-law scaling between the maximal landslide density and the maximal total rainfall was reported (Marc et al., 2018). High-resolution characterization of the rainfall spatiotemporal pattern triggering a landslide event remains challenging.

Last, it is still unclear if absolute rainfall (or soil moisture) is the best metric for landslide forecasting or if a relative rainfall amount, normalized by climate, would be more appropriate, assuming the zone of interest is in equilibrium with a certain rainfall amount. Indeed, rainfall threshold in different regions varies widely (Guzzetti et al., 2008), and normalizing event intensity by mean annual rainfall reduce somewhat the scatter between different study areas (Guzzetti et al., 2008; Pedrozzi, 2004; Zêzere et al., 2015). In Japan, soil water index normalized by its maximum local record over the past decade has also been shown to better correlate to landslide occurrence than absolute rainfall or absolute soil water index (Saito et al., 2010; Saito \& Matsuyama, 2012). The importance of rainfall history can be explained by considering a stochastic distribution of rainfall event coupled to hillslopes with a regolith layer thickening through time (because of weathering and/or colluvium deposition) until being removed during a storm causing failure (Benda \& Dunne, 1997; Iida, 1999 and Iida, 2004). These numerical studies clarified the impact of long-return-period storms and the controls on landslide average recurrence time but left unexplored the importance of spatial variations in extreme climatology for understanding landslide susceptibility.

Here, we use 26 years (1988-2013) of continuous weather radar measurements in Japan and a landslide inventory triggered by a large typhoon to address how the landslide spatial pattern relate to the event rain field and the spatial pattern of long-return-period rainfall event.

\section{Materials and Methods}

\subsection{Landslide Inventory and its Topographic and Lithological Context}

We focus on the landslides triggered by Typhoon Talas that poured heavy rainfall over the Kii Peninsula between the 30 August and the 5 September 2011. We use the landslide inventory of Marc et al. (2018), containing 1900 landslide polygons representing $12 \mathrm{~km}^{2}$ and distributed over an area of $\sim 5000 \mathrm{~km}^{2}$. The landslide mapping was initially done with post typhoon aerial photographs (Uchida et al., 2012) and then revised with pre- and post-event high-resolution, cloud-free, satellite imagery over most of the peninsula (Marc et al., 2018; Figure 1). As a result, the overall regional pattern must be robust even if some mapped landslides might have been incorrectly attributed to the typhoon in the South of the peninsula (Figure 1a). Scar areas $\left(\mathrm{A}_{\mathrm{s}}\right)$ were obtained by estimating polygon widths based on polygon geometry and assuming a scar aspect ratio of 1.5 (Domej et al., 2017) and were converted to volume with an empirical scaling (Larsen et al., 2010; see Marc et al., 2018 for details). Overall, they had a frequency of scar area with a mode of $200 \mathrm{~m}^{2}$ and a power law decay for the larger landslides, until a maximal size of $0.2 \mathrm{~km}^{2}$ (estimated as $8 \mathrm{Mm}^{3}$ ). Landslides with $\mathrm{A}_{\mathrm{s}}>10,000 \mathrm{~m}^{2}$ are expected to be predominantly bedrock, relatively deep-seated ( $>10-\mathrm{m}$ deep), and in the Kii Peninsula, they often display complex geotechnical and hydrological properties (e.g., failure plane along a local fault or a lithological transition; Chigira et al., 2013; Kojima et al., 2015). Deep landslides also incorporate rainfall coming from longer and more complex hydrological pathways, degrading direct links with rainfall measurements (Terlien, 1998). Therefore, we focus on the smaller $\left(\mathrm{A}_{\mathrm{s}}<10,000 \mathrm{~m}^{2}\right)$ and shallower $(<\sim 3 \mathrm{~m})$ landslides that are assumed to occur in a more homogeneous regolith and thus should be more strongly related to rainfall patterns (Figure 1). This excludes 54 deep, bedrock landslides distributed over the peninsula, representing $3 \%, 47 \%$, and $92 \%$ of the total number, area, and volume of the catalogue, respectively, discussed separately. 


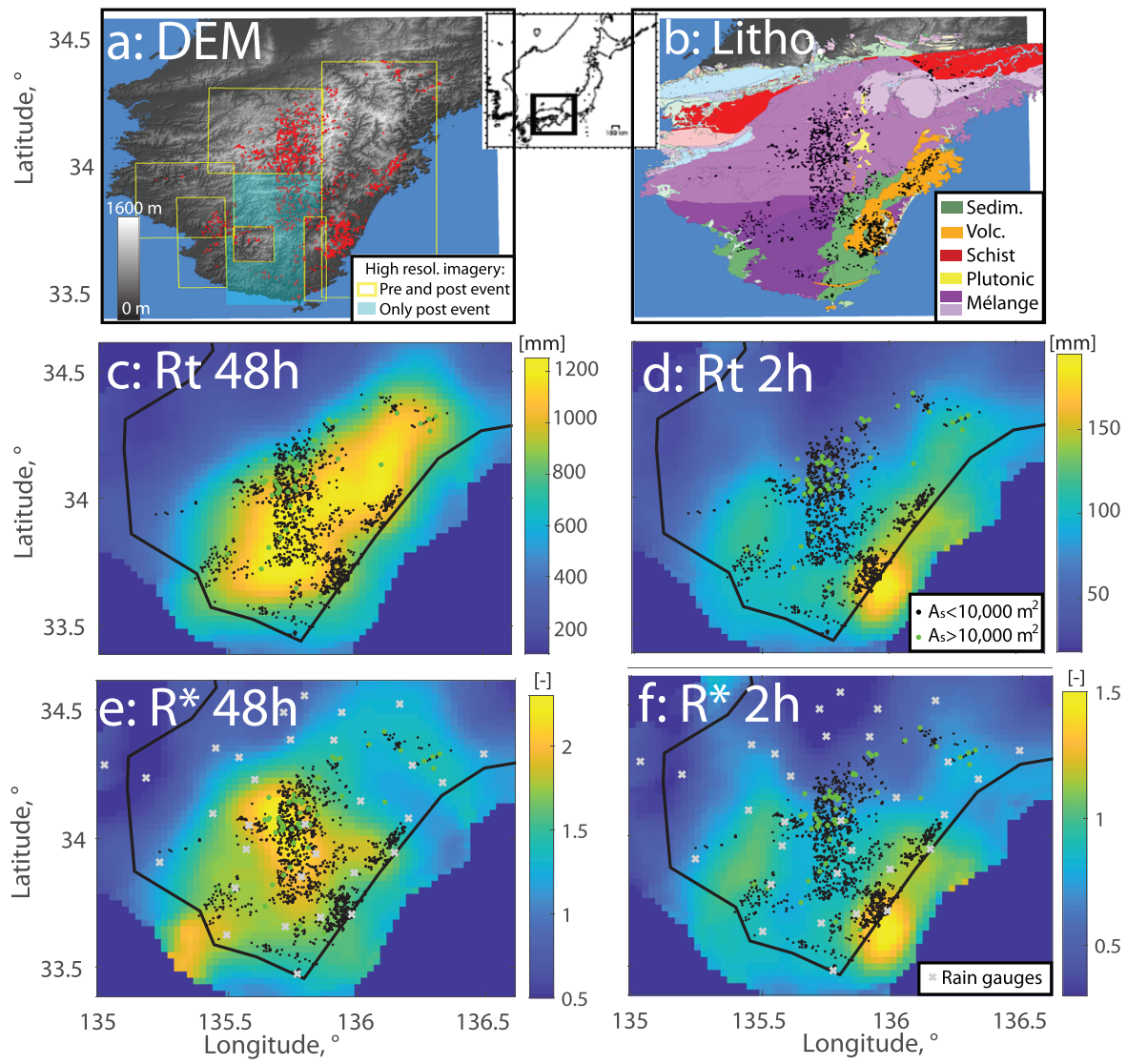

Figure 1. Hillshaded digital elevation model (a), lithological map (b), spatial pattern of the maximum accumulated rainfall during Typhoon Talas (Rt) over 48 and $2 \mathrm{hr}$ (c and d) and of the ratio between Rt and the estimated cumulative rainfall during a 10-year-return event of 48 and $2 \mathrm{hr}, \mathrm{R}^{*}$ (e and f).Inset: Location of the study area. DEM digital evaluation model.

We derived slope from the Shuttle Radar Topography Mission-1 arc second ( 30 m) digital elevation model (Farr et al., 2007) finding a unimodal distribution centered around $30^{\circ}$ (Marc et al., 2018), with gentler gradient toward the coastal areas. The landslides occur mainly within four rock types, including accretionary mélange (62\%), volcanic (27\%), sedimentary (9\%), and schist (2\%) lithologies (Figure 1 and ;supporting information, Figure S1).

\subsection{Meteorological Data}

We exploit the radar/rain gauge precipitation data set provided by the Japan Meteorological Agency for 26 years (1988-2013; Shimpo, 2001), allowing us to analyze rainfall at high spatial resolution ( kilometer) and to constrain the intensity of the Talas typhoon relative to past rainfall events. Measurements from each radar are cross-validated with the overlapping measurements from others and adjusted to rain gauge measurements if available in the same 1-km grid (31 in our area, Figure 1; Makihara, 1996). This product was shown to match independent measurement in the Tokyo area to reproduce the occurrence rate of rainfall from 5 to $70 \mathrm{~mm} / \mathrm{hr}$ derived from gauges and mostly retrieved 12 extreme (>100 mm/hr) rainfall events across Japan measured over 1 year (Makihara et al., 1996). Since 2006, the Japanese radar network constrain the hourly rainfall at a resolution of about $1 \mathrm{~km}$, but for homogeneity, the long-term record is using the lowest resolution of the network at its initiation in 1988, of $\sim 5 \mathrm{~km}$. This record was shown to be adequate (i.e., the hourly rainfall passed the homogeneity test) to retrieve the extreme rainfall with up to a 50-year return period (Saito \& Matsuyama, 2015; Urita et al., 2011).

Landslides can be triggered by short and intense burst of rainfall or by continuous rainfall accumulating water in the regolith over longer periods, the latter being more relevant for deeper landslides (Iverson, 
2000; Van Asch et al., 1999). Therefore, we explore the impact of the rainfall over several timescales by computing the maximum accumulated rainfall during $\mathrm{T}$ consecutive hours ( 1 to $72 \mathrm{hr}$; $\mathrm{Rt}$ ), for any cell of the radar data. As a result, a map of Rt represents the maximal rainfall forcing caused by storm but differ from a rainfall as various time periods are represented across the peninsula. Detailed timing of the landslides, not available yet except for the largest landslides (e.g., Yamada et al., 2012), would be needed to focus on specific time periods. For Typhoon Talas, the pattern of accumulated rainfall does not change much for periods longer than $72 \mathrm{hr}$, but longer periods may be important for other, long-lasting rainfall events.

Landslide triggering also depends on the hydrological and mechanical properties of the slope (Iverson, 2000; Terzaghi, 1943), terms that we are currently unable to constrain quantitatively. However, the landscape may be in equilibrium with the current climate, meaning that frequently occurring storms are unlikely to trigger extensive landsliding. Indeed, during a transient phase of landscape coevolution with the climate, such storms would repeatedly cause mass wasting, preferentially on the weakest or least able to drain slopes (e.g., Dietrich et al., 1995; D'Odorico \& Fagherazzi, 2003). In this framework, for similarly steep slopes receiving similar amount of rainfall during a storm, the ones with more frequent extreme rainfall should be less susceptible to landsliding. To test the relations between landslide pattern and local climate, we use the long record of high-resolution rainfall to constrain the mean climate and the recurrence of extreme rainfall in the Kii Peninsula.

First, we compute the mean annual rainfall and the mean seasonal rainfall during the typhoon season (April to October). Then, for all timescales $\mathrm{T}$, we compute the 26 maximum annual rainfall in every grid cell and perform L-moment fit (i.e., equating sample and theoretical L-moments computed with R, https://cran.rproject.org/web/packages/lmom/index.html; Hosking, 1990; Hosking \& Wallis, 1997) of the generalized extreme value distribution, to constrain the return of extreme events (Overeem et al., 2009; Saito \& Matsuyama, 2015). With the fitted distribution, we compute the 10 -year-return rainfall $\left(\mathrm{R}_{10}\right)$, and the jackknife standard deviation as an uncertainty measure (Saito \& Matsuyama, 2015), found to be always below $5 \%$ of $\mathrm{R}_{10}$. We focus on $\mathrm{R}_{10}$ as it is more robust, especially when computed for areas with shorter rainfall archive than Japan, but we note that in the Kii Peninsula, almost identical pattern, with 15-30\% more rainfall, are observed for the 20-year-return rainfall.

\subsection{Spatial Averaging, Fitting Procedure, and Residuals}

Using only rainfall and topographic information as predictors of landsliding, we seek to focus on first-order controls on landsliding by averaging all metrics within sliding windows of a given radius $\left(r\right.$, in the range $0.05^{\circ}$ to $\left.0.15^{\circ}\right)$. First, we produce 33-arc-second map containing the (i) the median slope $\left(\mathrm{S}_{50}\left[^{\circ}\right]\right)$ and (ii) the area of the grid cell with $\mathrm{S}>10^{\circ},\left(\mathrm{A}_{\mathrm{S}}>10\left[\mathrm{~m}^{2}\right]\right)$, considered minimum to allow landsliding (Meunier et al., 2007; Marc, Hovius, Meunier, Gorum, et al., 2016).

These two metrics are averaged within the sliding window, and we define a mean landslide density $\left(\mathrm{P}_{1 \mathrm{~s}}[-]\right)$ as

$$
P_{l s}=\frac{A_{t}}{A_{S>10}}
$$

with $A_{t}\left(m^{2}\right)$ and $A_{S}>10\left(\mathrm{~m}^{2}\right)$ the total landslide scar area and the total area allowing landsliding, respectively, within the averaging window. The mean rainfall forcing (Rt or $\mathrm{R}_{10}[\mathrm{~mm}]$ ) is computed as a weighted average of the rainfall amount within each cells present in the sliding window, with $\mathrm{A}_{\mathrm{S}}>10$ as weight, downweighting the rainfall over flat or submerged areas, which should not contribute to landsliding. We compute the rainfall anomaly as $\mathrm{R}^{*}=\mathrm{Rt} / \mathrm{R}_{10}(-)$.

We perform least-squares fitting of $\log \left(\mathrm{P}_{1 \mathrm{~s}}\right)$ against $\mathrm{S}_{50}$ and $\log \left(\mathrm{R}\right.$; Rt or $\mathrm{R}^{*}$ depending on the model chosen), to obtain an empirical function predicting landslide density as

$$
P_{l s}^{\prime}=k_{M}\left(\frac{R}{R_{0}}\right)^{k_{R}} \exp \left(\frac{S_{50}}{k_{S}}\right)
$$

where $\mathrm{P}_{l \mathrm{~s}}{ }^{\prime}$ is the predicted density, $\mathrm{R}_{0}$ is a reference rainfall equal to 1 or100 $\mathrm{mm}$ when $\mathrm{R}=\mathrm{Rt}$ or $\mathrm{R}^{*}$, respectively, and $\mathrm{k}_{\mathrm{M}}(-), \mathrm{k}_{\mathrm{R}}(-)$, and $\mathrm{k}_{\mathrm{S}}\left(^{\circ}\right)$ are constants representing (1) the landscape susceptibility to landsliding for a reference rainfall, (2) the dependence of landsliding on rainfall, and (3) on 

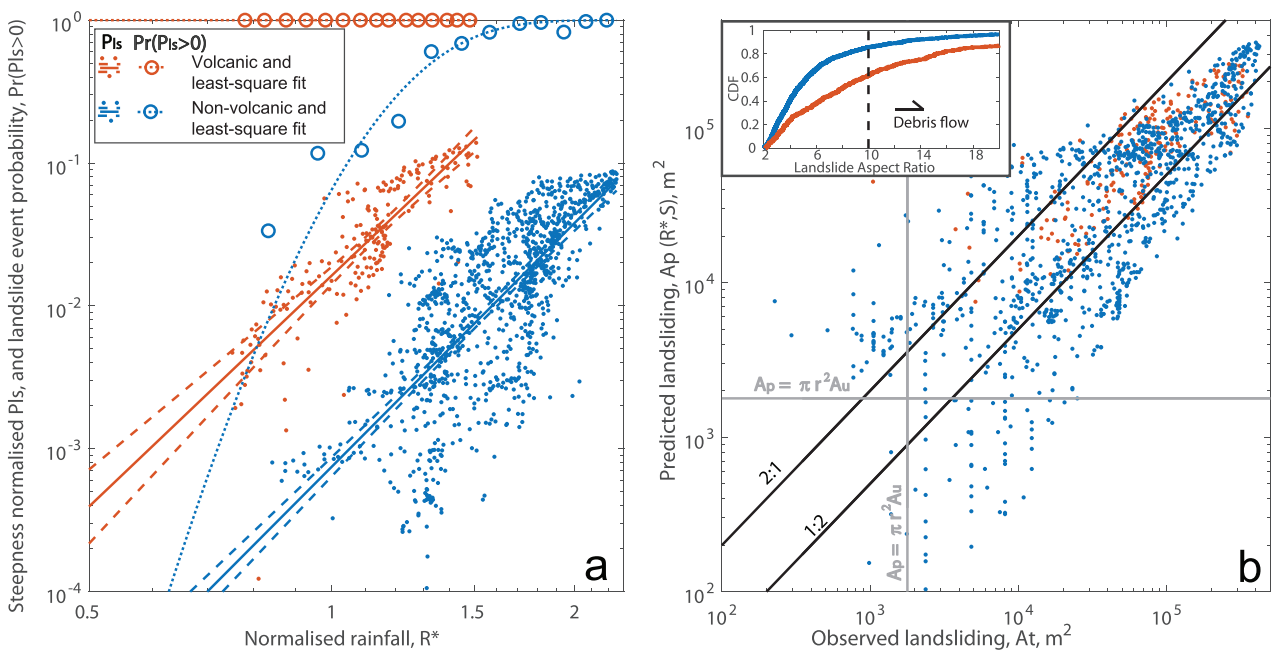

Figure 2. (a) Landslide density (dots) normalized for $\mathrm{S}_{50}=20^{\circ}$ and landslide event probability (circles) against normalized rainfall, for volcanic rocks ( $2 \mathrm{hr}$, red) and nonvolcanic rocks (48 hr, blue). Best fits of $\mathrm{P}_{\mathrm{ls}}$ are obtained for $\mathrm{k}_{\mathrm{R}}=5.2$ and $\mathrm{k}_{\mathrm{S}}=11^{\circ}\left(R^{2}=0.61\right)$ for the volcanic areas and $\mathrm{k}_{\mathrm{R}}=5.7$ and $\mathrm{k}_{\mathrm{S}}=25^{\circ}\left(R^{2}=0.71\right)$ or the nonvolcanic areas. (b) Predicted total scar area within a radius of $0.1^{\circ}$ against observed total scar area grey lines indicate uncertainty level used when computing model residuals (see section 2). Inset: CDF, cumulative distribution function of landslide aspect ratio.

steepness. The power law form is chosen following previous studies (Chen et al., 2013; Marc et al., 2018) but an exponential function of $\mathrm{R}$ gives only slightly worse fit and prediction. For $\mathrm{S}_{50}$, an exponential form performs better than a power law and allows comparison with previous work (Marc, Hovius, Meunier, Gorum, et al., 2016). To account for the fact that most grid cells are without any landslides, we bin all grid cells by their mean rainfall forcing and computed for each bin the proportion of grid cell with non-null landslide density, obtaining a probability of landslide occurrence $\operatorname{Pr}\left(\mathrm{P}_{1 \mathrm{~s}}>0\right.$; -$)$. We fit this probability with a two-parameter gamma cumulative distribution, chosen for its flexible functional form (Figure 2).

For each grid cell, we compute the predicted total landslide scar area within a radius of $r,\left(A_{p}\left[m^{2}\right]\right)$ as

$$
A_{P}=\operatorname{Pr}\left(P_{l s}>0\right) P_{l s}^{\prime} A_{S>10}
$$

We compute residuals for the $i$ th grid cell as $r s(i)=\log \left(A_{p} / A_{t} ;[-]\right)$. In areas with rainfall close to the threshold and/or areas of a low proportion of steep topography, $A_{p}$ may be very low, but the residuals may still be infinite if no landslides were reported in this zone. Therefore, we consider an uncertainty level arbitrary set at $A_{u}=6\left[\mathrm{~m}^{2} \mathrm{~km}^{-2}\right]$, that corresponds to about three landslides with scar areas equal to the 10th percentile of the area distribution $\left(\sim 200 \mathrm{~m}^{2}\right)$ every $100 \mathrm{~km}^{2}$. This is near the resolution limit of most landslide inventories and in zones where $A_{p}<=\left(A_{u} A_{S}>10\right)$ and $A_{t}=0$ residuals are not meaningful and set to rs $=0$. Given that small landslides may also be missing in the catalogue, we consider rs $(i)=\log \left(A_{p} / A_{u}\right)$ where $A_{p}>\left(A_{u} A_{S}>\right.$ s10 $)$ and $A_{t}=0$. The residuals are thus finite everywhere and the quality of the model can be summarized by a root mean square error (RMSE; [-]):

$$
\operatorname{RMSE}=\sqrt{\sum_{i} r S(i)^{2}}
$$

The processing steps described above can be applied over the whole domain, assumed to be homogeneous or within specific lithological units. In this case, the fitting procedure considers only the grid points in which at least two-thirds of the landslide scars belong to the chosen lithology. The final prediction is then merging the independent prediction with a weighted average, where the weights are the proportion of each lithology within the sliding window. 


\section{Results}

\subsection{Qualitative Correlation With the Spatial Pattern of Rainfall}

The pattern of accumulated rainfall at all timescales present a southwest-northwest band of intense rainfall, roughly parallel to the (southeastern) coastline of the study area (Figure 1 and supporting information, Figure S2). At short timescales (1-6 hr), the band is less continuous and roughly located over the coast while over longer timescales, (48-72 hr) the band is wider, continuous, and extends over the mountain range from 135.5 to $136.3^{\circ} \mathrm{E}$. This transition highlights the importance of orographic effects on the rainfall over longer timescales $(>24 \mathrm{hr})$.

The landslide spatial pattern poorly matches any of these rainfall patterns, with most of the landslides distributed within a north-south oriented valley (centered at $135.8^{\circ} \mathrm{E}$ ), with two secondary clusters on the southeast coast, and smaller clusters near $33.8^{\circ} / 135.5^{\circ}$ and $34.3^{\circ} / 136.3^{\circ}$. Almost no new landslides occurred on the eastern flank of the highest crests $\left(34.1^{\circ} \mathrm{N} / 136^{\circ} \mathrm{E}\right)$ while they receive as much or more rainfall than the valley with most landslides. However, the decadal record of rainfall indicates that the 10-year-return 48-hr rainfall is about two times larger in the former area than in the latter (supporting information, Figure S3). Thus, the rainfall anomaly $\mathrm{R}^{*}$ is $>2$ in the valley where most landslides occurred, between 1.5 and 2 in the coastal areas and $\leq 1$ where few landslides occurred (Figure 1 and supporting information, Figure S4). In contrast, mean annual and seasonal rainfall are less focused than $\mathrm{R}_{10}$ and yield an anomaly that poorly matches the landslide pattern (Figure 1e and supporting information, Figure S5d).

Last, two coastal landslide clusters display a high density of landslides compared to other zones with $\mathrm{R}^{*} \sim 1.5$. These landslides occurred within volcanic rocks and exhibit a much larger proportion of very mobile debris flows ( $40 \%)$, with aspect ratio $>10$, than landslides in other rock types (10\%; Figure 2 inset). They seem to better match the pattern of short, high-intensity rainfall defined by Rt and $\mathrm{R}^{*}$ at the 1- to 3-hr timescale (Figures 1 and S4).

\subsection{Prediction of Landslide Pattern Based on Absolute Rainfall and Rainfall Anomalies}

The spatial pattern of landsliding agrees better with the rainfall anomaly at long timescales, although the landsliding in the volcanic rocks may be due to shorter timescales and different hydrological processes. We quantify the fit and prediction quality obtained with event rainfall and rainfall anomaly at several timescales. Then, we assess the robustness of the best empirical landslide-pattern prediction to various parameter variations and landslide metrics.

Prediction based on Rt, considering a single or two lithological units, led to significantly poorer spatial pattern prediction than when considering $\mathrm{R}^{*}$ (Figure 3 ). This was also true when averaging rainfall ( $\mathrm{Rt}$ and $\mathrm{R}^{*}$ ) at any timescales. With $r=0.1^{\circ}$, the best RMSE is obtained when using $S_{50}, R^{*} 2 \mathrm{hr}$ over the volcanic areas and $\mathrm{R}^{*} 48 \mathrm{hr}$ elsewhere. Using only $\mathrm{R}^{*}, 48 \mathrm{hr}$ over the full domain underpredicts the landsliding in the volcanic areas but remains better than fitting two lithologies with Rt (Figure 3). When using Rt (with one or two lithologies), landsliding is substantially underpredicted ( tenfold) in the center of the Peninsula and overpredicted in broad areas to the east (Figure 3 and supporting information, Figure S6). The only disadvantage of $\mathrm{R}^{*}$ over $\mathrm{Rt}$ is a fringe of overprediction on the northern and western part of the area affected by landsliding and an underprediction by about a factor of 3 in the northeastern landslide cluster, mostly underlain by schist.

Overall, the best model prediction based on $\mathrm{R}^{*}$ ( 48 and $2 \mathrm{hr}$ ) and $\mathrm{S}_{50}$ explains $>60 \%$ of the variance in the two lithologies and is within a factor 2 and 3 of the observed area in 58 and $79 \%$ of the grid cells with reported landsliding, respectively. The best prediction is also below $\mathrm{A}_{\mathrm{u}}$ in $79 \%$ of the area without reported landslides (Figures 2 and 3). Overprediction by more than a factor 3 represents $\sim 10 \%$ of the grid cells with $A_{p}>A_{u}$. Additionally, the best $\mathrm{R}^{*}$ model yields similar rainfall susceptibility constants in the two lithologies with $\mathrm{k}_{\mathrm{R}} \sim 5.2-5.7$. In contrast, with $\mathrm{R}_{\mathrm{t}}$, the fit $R^{2}$ is near zero in the nonvolcanic lithologies, and $\mathrm{k}_{\mathrm{R}}$ differ from 3 to 6 in the two units (Figure S6). The best-model residuals in nonvolcanic lithologies still exhibit some correlation with $\mathrm{S}_{50}$ ones could be further subdivided by rock type (supporting information, Figure S7). Assessment and comparison of models with a set of parameters for each rock type is beyond the scope of our study, which aim to identify the core variables driving the large scale pattern of storminduced landsliding. 

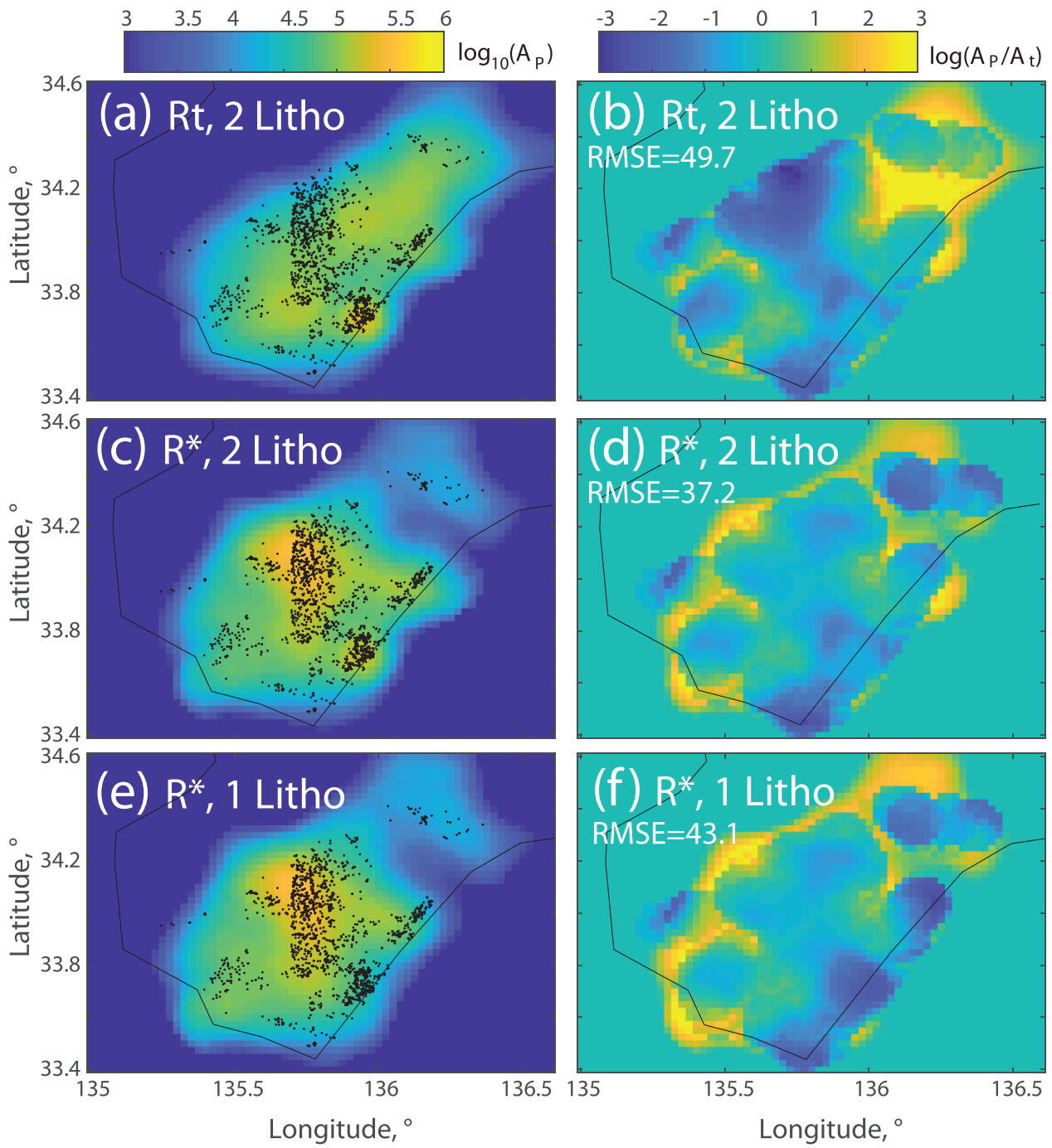

Figure 3. Map view of the landslide area within a radius of $0.1^{\circ}$ predicted by equation $(3)(\mathrm{a}, \mathrm{c}$, and e) and of the prediction residuals during 48 and $2 \mathrm{hr}$ over the nonvolcanic and volcanic areas (a-d) and $48 \mathrm{hr}$ over the whole domain (e and f), with $\mathrm{R}=\mathrm{Rt}\left(\mathrm{a}\right.$ and $\mathrm{b}$ ) and $\mathrm{R}=\mathrm{R}^{*}(\mathrm{c}-\mathrm{f})$, respectively. Black dots are landslides. RMSE, root mean square error.

To validate the robustness of our relation between landsliding, $\mathrm{S}_{50}$, and $\mathrm{R}^{*}$ at several timescales, we performed a series of sensitivity tests for other parameters of the method. We obtain similar results when considering $48 \mathrm{hr}$ and 1-3 hr and a progressive degradation of the fit and prediction when considering shorter and longer timescales for the nonvolcanic and volcanic lithologies, respectively. The overall pattern and the relative difference between the RMSE of Rt and $\mathrm{R}^{*}$ models is preserved when reducing the uncertainty threshold $\mathrm{A}_{\mathrm{u}}$ or when varying the averaging radius $\left(\mathrm{r}=0.05^{\circ}\right.$ to $0.15^{\circ}$; supporting information, Figures $\mathrm{S} 8$ and S9). The total landslide number, the whole area (including landslide runout) or the volume follow a similar pattern and can be predicted similarly, when restraining the prediction to shallow $(<3 \mathrm{~m}$ ) landslides (supporting information, Figure S10). In contrast, even if the deep-seated landslides did mostly occur in areas with high $\mathrm{R}^{*}$ (Figure 1), their inclusion degrade substantially the RMSE of the prediction of the total landslide area and even more for the landslide total volume (supporting information, Figure S11).

\section{Discussion}

We show that the spatial pattern of landsliding poorly matches the rainfall pattern during the event, at any considered timescales, but agrees with the pattern of the rainfall anomaly relative to 10-year-return rainfall events. 
Rainfall-induced landsliding is generally attributed to pore-water pressure developing on the landslidefailure planes, resulting from the infiltration and percolation of rainfall and/or groundwater flow from draining slopes (Iverson, 2000; Terzaghi, 1943; Wilson \& Wieczorek, 1995). There is an ongoing shift from rainfall-based landslide thresholds to hydrological thresholds, accounting for antecedent soil moisture (e.g., Bogaard \& Greco, 2018; Osanai et al., 2010; Thomas et al., 2018). However, during large storms or typhoons, the accumulated rainfall amounts are so large that they may outweigh possible effects associated with antecedent soil moisture levels. Additionally, the prediction enhancement obtained with rainfall anomaly may suggest the existence of substantial variations in hydrological and mechanical properties of the hillslopes over moderate scales $(\sim 10-20 \mathrm{~km})$ that could not be inferred from the digital elevation model of lithological map only, thus, limiting the use of physical models requiring constraints on these properties (e.g., Baum et al., 2010; Malet et al., 2005; von Ruette et al., 2014). In the framework of coevolving hillslopes, such spatial variability of hillslope properties may result from a long-term difference in extreme rainfall recurrence times and associated landsliding selectively removing the least stable slopes. This is consistent with the fact that $\mathrm{R}_{10}$ provides adequate normalization, in contrast to the mean annual or seasonal rainfall that could drive landscape coevolution through other processes such as weathering (Figure S5). In the Kii Peninsula, the differences in extreme rainfall likely arise because of high coastal relief and typhoons preferentially bringing moisture from the southeast, causing strongly localized orographic effects (Shige et al., 2012). Thus, the use of rainfall anomaly may be especially important in similar settings (common in Asia), as well as in inland areas where topography causes a rain shadow. In any case, our results suggest that, in the study area, the 10-year-return rainfall is a good proxy for the "extreme" climatology over longer time periods (as suggested by its similarity with the 20-year-return rainfall), required for hillslope coevolution through repeated landsliding (e.g., 100 to 1000 years). Indeed, although some landsliding may occur every few years (Imaizumi et al., 2008; Saito et al., 2014), the last landslide event with a magnitude similar to the one of 2011 in the Kii Peninsula occurred 120 years ago, in August 1889 (Hirano et al., 1984; Inoue \& Doshida, 2012). In regions with slower erosion, and thus slower landscape coevolution, or less stable extreme climatology, rainfall with return times longer than 10 years may be required to understand landslide pattern.

We also found that the volcanic rocks have a higher $\mathrm{k}_{\mathrm{M}}$, lower $\mathrm{k}_{\mathrm{S}}$, and are most related to short timescales high-intensity rainfall anomalies and resulted in landslides more prone to transform into debris flow (Figures 1 and 2). This requires that rock types modulates not only material strength $\left(\mathrm{k}_{\mathrm{M}}\right.$; Parise \& Jibson, 2000; Korup, 2008) but also hydrological properties (e.g., through fracturation and weathering). The volcanic rock are made of porphyric granite, likely strong, but overlain by 1-3 $\mathrm{m}$ of a highly weathered and jointed, clay-rich regolith with residuals spherical corestones, within which almost all landslides initiated (Hirata \& Chigira, 2015). Constraining hydrological and mechanical properties of such complex material is beyond the scope of this study, but we speculate that heterogeneity allowed a fast drainage, and thus pore fluid pressure could only increase during the highest intensity rainfall. Volcanic rocks seem also more susceptible to $\mathrm{S}_{50}$, with $\mathrm{k}_{\mathrm{S}}=10^{\circ}$ almost equal to the constant modulating the exponential increase of earthquake-induced landslide volume with landscape steepness (Marc, Hovius, Meunier, Gorum, et al., 2016). In contrast, the high $\mathrm{k}_{\mathrm{S}}$ of the nonvolcanic rocks indicate limited increase of landsliding for steeper slopes. Rainfall-induced landslides from various storms were reported to locate on average slopes rather than on the steepest slopes of the landscape, possibly because high pore-fluid pressures were anticorrelated to slope gradients for hydrological reasons (Marc et al., 2018). However, we report that, according to the lithology, slope gradients may enhance or limit landsliding as suggested by the residuals of the prediction (Figure S7). Again, this suggests variable hydrological properties that should be investigated with field measurements.

We acknowledge that our methods, although assessing the effect of multiple timescales, neglect the combination of multiple scales or sequencing effects (see D'Odorico et al., 2005). In our case, averaging $\mathrm{R}^{*}$ over multiple timescales degraded the correlation with landslides except when limiting to similar anomalies (i.e., 48-72 hr in the nonvolcanic and 1-3 hr in the volcanic rocks; Figure S4). For sequencing, we computed the intensity and timing of the maximum 3-hr rainfall occurring within the wettest $48 \mathrm{hr}$ and found a complex timing pattern, uncorrelated with model residuals, with late bursts over the coastal areas and early bursts on the northern part of the range (supporting information, Figure S12). We also find that the rainfall burst intensity agrees with Rt $3 \mathrm{hr}$, implying a superposition of timescales that may have mattered for the landslides in the volcanic rocks (Figures S2 and S12). Therefore, hydrological modeling is likely required to deconvolve the different timescales in these areas. 
Finally, an important caveat is the limited prediction power for large, deep landslides, and thus on total landslide volume and associated erosion and sediment fluxes. Although high $\mathrm{R}^{*}$ seems essential and is a better predictor than Rt, for local groups of deep landslides (Kinoshita et al., 2013; Saito \& Matsuyama, 2012), it is insufficient, as large landslides may depend on local conditions independent of the rainfall pattern (present or past). For example, in the Kii Peninsula, large Talas landslides were related to stratigraphic or geologic structures forming preexisting weakness planes (Chigira et al., 2013; Kojima et al., 2015) and/or longterm gravitational deformation (Chigira et al., 2013).

\section{Conclusions}

Quantitative links between the pattern of landslide density and the rainfall anomaly at timescales that may be set by different lithologies open important pathways for future research. In terms of landslide hazard, it suggests that susceptibility maps could incorporate long-return-period rainfall maps but also that rock type (and/or soil types) may not only control the propensity to failure of the material but also the rainfall metric correlated to failure. To explain the link between rainfall anomaly and landslide pattern, we propose a testable hypothesis, in which the coevolution of hillslopes with climate (Dietrich et al., 1995; D'Odorico \& Fagherazzi, 2003; Iida, 1999), would lead to a correlation between rainfall amount during long-return-period rainfall and the spatial pattern of regolith properties. Spatially distributed measurements of regolith depth, strength, and draining properties in the Kii Peninsula are required to validate such hypothesis. Our results also open pathways toward new early warning systems, based on meteorological nowcast and long-term rainfall archives, and able to give a landslide alert including the patterns of the expected magnitude of landsliding. Scaling for other cases in Japan and elsewhere must be quantified, to assess the variability of the empirical constants found in this study. Detailed rainfall information is required by our approach and may be difficult to obtain in many places. In this context, quantitative rainfall estimates derived by satellites (e.g., Beck et al., 2017) may potentially provide both spatially extensive constraint on events and a characterization of past rainfall frequency. However, important bias in retrieving orographic rainfall has been reported (Shige et al., 2012; Yamamoto et al., 2017), and the validation of rainfall anomaly maps obtained by such products in landslide prone terrains should be undertaken.

The authors have no conflicts of interest with this work. OM work was carried with the support of the CNES (French National Space Agency) through a postdoctoral grant (project STREAM-LINE GLIDERS “SaTellite-based Rainfall Measurement and LandslIde detectioN for Global LandslIDE-Rainfall Scaling") and of the CNRS-INSU through the program TelluS (Project: Lois d'échelle globale entre fortes précipitations et intensité de glissements de terrain: Analyses à l'échelle de bassins versants). HS was supported by a Kanto Gakuin University Research Grant for Young Researchers. The authors thank Thom Bogaard for fruitful discussion and two anonymous reviewers for constructive comments. Rainfall radar data (R/A) are available from the Japan Meteorological Agency. Geological maps of the Kii Peninsula are available through the Geological Survey of Japan (https://www.gsj.jp/Map/index_e. html). The Shuttle Radar Topography Mission-30-m digital elevation model data set (NASA JPL, 2013) was retrieved from the online Global Data Explorer, courtesy of the NASA EOSDIS Land Processes Distributed Active Archive Center (LP DAAC), USGS/Earth Resources Observation and Science (EROS) Center, Sioux Falls, South Dakota, (https://gdex.cr.usgs.gov/gdex/ , last access: 26 February 2019).

\section{References}

Baum, R. L., Godt, J. W., \& Savage, W. Z. (2010). Estimating the timing and location of shallow rainfall-induced landslides using a model for transient, unsaturated infiltration. Journal of Geophysical Research Earth Surface, 115, F03013. https://doi.org/10.1029/ 2009JF001321

Beck, H. E., Vergopolan, N., Pan, M., Levizzani, V., van Dijk, A. I. J. M., Weedon, G., et al. (2017). Global-scale evaluation of 23 precipitation datasets using gauge observations and hydrological modeling. Hydrology and Earth System Sciences Discussions, 2017, 1-23. https://doi. org/10.5194/hess-2017-508

Benda, L., \& Dunne, T. (1997). Stochastic forcing of sediment supply to channel networks from landsliding and debris flow. Water Resources Research, 33(12), 2849-2863. https://doi.org/10.1029/97WR02388

Bogaard, T., \& Greco, R. (2018). Invited perspectives: Hydrological perspectives on precipitation intensity-duration thresholds for landslide initiation: Proposing hydro-meteorological thresholds. Natural Hazards and Earth System Sciences, 18(1), 31-39. https://doi.org/10.5194/ nhess-18-31-2018

Caine, N. (1980). The rainfall intensity: Duration control of shallow landslides and debris flows. Geografiska Annaler. Series A, Physical Geography, 62(1/2), 23-27. https://doi.org/10.2307/520449

Chen, Y.-C., Chang, K., Chiu, Y.-J., Lau, S.-M., \& Lee, H.-Y. (2013). Quantifying rainfall controls on catchment-scale landslide erosion in Taiwan. Earth Surface Processes and Landforms, 38(4), 372-382. https://doi.org/10.1002/esp.3284

Chigira, M., Tsou, C.-Y., Matsushi, Y., Hiraishi, N., \& Matsuzawa, M. (2013). Topographic precursors and geological structures of deepseated catastrophic landslides caused by Typhoon Talas. Geomorphology, 201, 479-493. https://doi.org/10.1016/j. geomorph.2013.07.020

D'Odorico, P., Fagherazzi, S., \& Rigon, R. (2005). Potential for landsliding: Dependence on hyetograph characteristics. Journal of Geophysical Research Earth Surface, 110, F01007. https://doi.org/10.1029/2004JF000127

Dietrich, W. E., Reiss, R., Hsu, M.-L., \& Montgomery, D. R. (1995). A process-based model for colluvial soil depth and shallow landsliding using digital elevation data. Hydrological Processes, 9(3-4), 383-400. https://doi.org/10.1002/hyp.3360090311

D'Odorico, P., \& Fagherazzi, S. (2003). A probabilistic model of rainfall-triggered shallow landslides in hollows: A long-term analysis. Water Resources Research, 39(9), ESG6-1. https://doi.org/10.1029/2002WR001595

Domej, G., Bourdeau, C., \& Lenti, L. (2017). Mean landslide geometries inferred from a global database of earthquake- and nonEarthquake-triggered landslides. Italian Journal of Engineering Geology and Environment, 2, 87-107. https://doi.org/10.4408/ IJEGE.2017-02.O-05

Farr, T. G., Rosen, P. A., Caro, E., Crippen, R., Duren, R., Hensley, S., et al. (2007). The Shuttle Radar Topography Mission. Reviews of Geophysics, 45, RG2004. https://doi.org/10.1029/2005RG000183

Guzzetti, F., Peruccacci, S., Rossi, M., \& Stark, C. P. (2008). The rainfall intensity-duration control of shallow landslides and debris flows: An update. Landslides, 5(1), 3-17. https://doi.org/10.1007/s10346-007-0112-1 
Hirano, M., Suwa, H., Ishii, T., Fujita, T., \& Gocho, Y. (1984). Reexamination of the Totsukawa hazard in August 1889 with special reference to geologic control of large-scale landslides. Bulletin of the Disaster Prevention Research Institute, Kyoto University, 27(1), 369-386.

Hirata, Y., \& Chigira, M. (2015). Geological and geomorphological features of landslides induced by 2011 Typhoon Talas in a granite porphyry area, 8 .

Hosking, J. R. M. (1990). L-moments: Analysis and estimation of distributions using linear combinations of order statistics. Journal of the Royal Statistical Society: Series B Methodological, 52(1), 105-124.

Hosking, J. R. M., \& Wallis, J. R. (1997). Regional frequency analysis: An approach based on L-moments. Cambridge; New York: Cambridge University Press. Retrieved from. https://trove.nla.gov.au/version/27150495

Iida, T. (1999). A stochastic hydro-geomorphological model for shallow landsliding due to rainstorm. Catena, 34(3), 293-313. https://doi. org/10.1016/S0341-8162(98)00093-9

Iida, T. (2004). Theoretical research on the relationship between return period of rainfall and shallow landslides. Hydrological Processes, 18(4), 739-756. https://doi.org/10.1002/hyp.1264

Imaizumi, F., Sidle, R. C., \& Kamei, R. (2008). Effects of forest harvesting on the occurrence of landslides and debris flows in steep terrain of central Japan. Earth Surface Processes and Landforms, 33(6), 827-840. https://doi.org/10.1002/esp.1574

Inoue, K., \& Doshida, S. (2012). Comparison of distribution of disasters occurring in 1889 and 2011 on Kii Peninsula. Journal of the Japan Society of Erosion Control Engineering, 65(3), 42-46. https://doi.org/10.11475/sabo.65.3_42

Iverson, R. M. (2000). Landslide triggering by rain infiltration. Water Resources Research, 36(7), 1897-1910. https://doi.org/10.1029/ 2000WR900090

Keefer, D. K. (2002). Investigating landslides caused by earthquakes-A historical review. Surveys in Geophysics, 23(6), 473-510. https://doi. org/10.1023/A:1021274710840

Keefer, D. K., \& Larsen, M. C. (2007). Assessing landslide hazards. Science, 316(5828), 1136-1138. https://doi.org/10.1126/science.1143308

Kinoshita, A., Kitagawa, S., Uchida, T., Kaihara, S., Takemoto, H., \& Tadakuma, N. (2013). Rainfall conditions result in intensive deepseated landslides: Rainfall analysis for typhoon No. 12 in 2011. Journal of the Japan Society of Erosion Control Engineering, 66(3), 24-31. https://doi.org/10.11475/sabo.66.3_24

Kojima, S., Nagata, H., Yamashiroya, S., Iwamoto, N., \& Ohtani, T. (2015). Large deep-seated landslides controlled by geologic structures: Prehistoric and modern examples in a Jurassic subduction-accretion complex on the Kii Peninsula, central Japan. Engineering Geology, 186, 44-56. https://doi.org/10.1016/j.enggeo.2014.10.018

Korup, O. (2008). Rock type leaves topographic signature in landslide-dominated mountain ranges. Geophysical Research Letters, 35, GL034157. https://doi.org/10.1029/2008GL034157

Larsen, I. J., Montgomery, D. R., \& Korup, O. (2010). Landslide erosion controlled by hillslope material. Nature Geoscience, 3(4), 247-251.

Li, G., West, A. J., Densmore, A. L., Jin, Z., Zhang, F., Wang, J., Clark, M., \& Hilton, R. G. (2017). Earthquakes drive focused denudation along a tectonically active mountain front. Earth and Planetary Science Letters, 472, 253-265. https://doi.org/10.1016/j. epsl.2017.04.040

Makihara, Y. (1996). A method for improving radar estimates of precipitation by comparing data from radars and rain gauges. Journal of the Meteorological Society of Japan. Ser. II, 74(4), 459-480. https://doi.org/10.2151/jmsj1965.74.4_459

Makihara, Y., Uekiyo, N., Tabata, A., \& Abe, Y. (1996). Accuracy of radar-AMeDAS precipitation. IEICE Transactions on Communications, 79(6), 751-762. https://ci.nii.ac.jp/naid/110003217623

Malet, J.-P., van Asch, T. W. J., van Beek, R., \& Maquaire, O. (2005). Forecasting the behaviour of complex landslides with a spatially distributed hydrological model. Natural Hazards and Earth System Sciences, 5(1), 71-85. https://doi.org/10.5194/nhess-5-71-2005

Marc, O., Hovius, N., \& Meunier, P. (2016). The mass balance of earthquakes and earthquake sequences. Geophysical Research Letters, 43, 3708-3716. https://doi.org/10.1002/2016GL068333

Marc, O., Meunier, P., \& Hovius, N. (2017). Prediction of the area affected by earthquake-induced landsliding based on seismological parameters. Natural Hazards and Earth System Sciences, 17(7), 1159-1175. https://doi.org/10.5194/nhess-17-1159-2017

Marc, O., Behling, R., Andermann, C., Turowski, J. M., Illien, L., Roessner, S., \& Hovius, N. (2019). Long-term erosion of the Nepal Himalayas by bedrock landsliding: The role of monsoons, earthquakes and giant landslides. Earth Surface Dynamics, 7(1), 107-128. https://doi.org/10.5194/esurf-7-107-2019

Marc, O., Hovius, N., Meunier, P., Gorum, T., \& Uchida, T. (2016). A seismologically consistent expression for the total area and volume of earthquake-triggered landsliding. Journal of Geophysical Research: Earth Surface, 121, 640-663. https://doi.org/10.1002/2015JF003732

Marc, O., Stumpf, A., Malet, J.-P., Gosset, M., Uchida, T., \& Chiang, S.-H. (2018). Initial insights from a global database of rainfall-induced landslide inventories: The weak influence of slope and strong influence of total storm rainfall. Earth Surface Dynamics, 6(4), 903-922. https://doi.org/10.5194/esurf-6-903-2018

Meunier, P., Hovius, N., \& Haines, A. J. (2007). Regional patterns of earthquake-triggered landslides and their relation to ground motion. Geophysical Research Letters, 34, L20408. https://doi.org/10.1029/2007GL031337

Meunier, P., Uchida, T., \& Hovius, N. (2013). Landslide patterns reveal the sources of large earthquakes. Earth and Planetary Science Letters, 363, 27-33. https://doi.org/10.1016/j.epsl.2012.12.018

NASA JPL (2013). NASA Shuttle Radar Topography Mission Global 1 arc second [Data set], NASA EOSDIS Land Processes DAAC, https:// doi.org/10.5067/MEaSUREs/SRTM/SRTMGL1.003

Osanai, N., Shimizu, T., Kuramoto, K., Kojima, S., \& Noro, T. (2010). Japanese early-warning for debris flows and slope failures using rainfall indices with radial basis function network. Landslides, 7(3), 325-338. https://doi.org/10.1007/s10346-010-0229-5

Overeem, A., Buishand, T. A., \& Holleman, I. (2009). Extreme rainfall analysis and estimation of depth-duration-frequency curves using weather radar. Water Resources Research, 45, WR007869. https://doi.org/10.1029/2009WR007869

Parise, M., \& Jibson, R. W. (2000). A seismic landslide susceptibility rating of geologic units based on analysis of characteristics of landslides triggered by the 17 January, 1994 Northridge, California earthquake. Engineering Geology, 58(3-4), 251-270. https://doi.org/10.1016/ S0013-7952(00)00038-7

Pedrozzi, G. (2004). Triggering of landslides in Canton Ticino (Switzerland) and prediction by the rainfall intensity and duration method. Bulletin of Engineering Geology and the Environment, 63(4), 281-291. https://doi.org/10.1007/s10064-004-0240-y

Reid, L. M. (1998). Calculation of average landslide frequency using climatic records. Water Resources Research, 34(4), 869-877. https://doi. org/10.1029/97WR02682

Saito, H., Korup, O., Uchida, T., Hayashi, S., \& Oguchi, T. (2014). Rainfall conditions, typhoon frequency, and contemporary landslide erosion in Japan. Geology, 42(11), 999-1002. https://doi.org/10.1130/G35680.1

Saito, H., \& Matsuyama, H. (2015). Probable hourly precipitation and soil water index for 50-yr recurrence interval over the Japanese Archipelago. SOLA, 11(0), 118-123. https://doi.org/10.2151/sola.2015-028 
Saito, H., Nakayama, D., \& Matsuyama, H. (2010). Two types of rainfall conditions associated with shallow landslide initiation in Japan as revealed by normalized soil water index. Sola, 6, 57-60. https://doi.org/10.2151/sola.2010-015

Saito, H., \& Matsuyama, H. (2012). Catastrophic landslide disasters triggered by record-breaking rainfall in Japan: Their accurate detection with normalized soil water index in the Kii Peninsula for the year 2011. Sola, 8, 81-84. https://doi.org/10.2151/sola.2012-021

Shige, S., Kida, S., Ashiwake, H., Kubota, T., \& Aonashi, K. (2012). Improvement of TMI rain retrievals in mountainous areas. Journal of Applied Meteorology and Climatology, 52(1), 242-254. https://doi.org/10.1175/JAMC-D-12-074.1

Shimpo, A. (2001). Radar/raingauge-analyzed precipitation (I). Tenki, 48, 579-583.

Strauch, R., Istanbulluoglu, E., Nudurupati, S. S., Bandaragoda, C., Gasparini, N. M., \& Tucker, G. E. (2018). A hydroclimatological approach to predicting regional landslide probability using Landlab. Earth Surface Dynamics, 6(1), 49-75. https://doi.org/10.5194/esurf6-49-2018

Terlien, M. T. J. (1998). The determination of statistical and deterministic hydrological landslide-triggering thresholds. Environmental Geology, 35(2), 124-130. https://doi.org/10.1007/s002540050299

Terzaghi, K. (1943). Effect of seepage on the conditions for equilibrium in ideal sand. In Theoretical Soil Mechanics (pp. 235-264). New York: John Wiley \& Sons, Ltd. https://doi.org/10.1002/9780470172766.ch12

Thomas, M. A., Mirus, B. B., \& Collins, B. D. (2018). Identifying physics-based thresholds for rainfall-induced landsliding. Geophysical Research Letters, 45(18), 9651-9661. https://doi.org/10.1029/2018GL079662

Uchida, T., Sato, T., Mizuno, M., \& Okamoto, A. (2012). The role of rainfall magnitude on landslide characteristics triggered by Typhoon Tales, 2011. Civil Engineering Journal, 54, 10-13. (in Japanese)

Urita, S., Saito, H., \& Matsuyama, H. (2011). Temporal and spatial discontinuity of radar/raingauge-analyzed precipitation that appeared in relation to the modification of its spatial resolution. Hydrological Research Letters, 5, 37-41. https://doi.org/10.3178/hrl.5.37

Van Asch, T. W. J., Buma, J., \& Van Beek, L. P. H. (1999). A view on some hydrological triggering systems in landslides. Geomorphology, 30(1), 25-32. https://doi.org/10.1016/S0169-555X(99)00042-2

von Ruette, J., Lehmann, P., \& Or, D. (2014). Effects of rainfall spatial variability and intermittency on shallow landslide triggering patterns at a catchment scale. Water Resources Research, 50, 7780-7799. https://doi.org/10.1002/2013WR015122

Wilson, R. C., \& Wieczorek, G. F. (1995). Rainfall thresholds for the initiation of debris flows at La Honda, California. Environmental \& Engineering Geoscience, I(1), 11-27. https://doi.org/10.2113/gseegeosci.I.1.11

Yamada, M., Matsushi, Y., Chigira, M., \& Mori, J. (2012). Seismic recordings of landslides caused by Typhoon Talas (2011), Japan. Geophysical Research Letters, 39, GL052174. https://doi.org/10.1029/2012GL052174

Yamamoto, M. K., Shige, S., Yu, C.-K., \& Cheng, L.-W. (2017). Further improvement of the heavy orographic rainfall retrievals in the GSMaP algorithm for microwave radiometers. Journal of Applied Meteorology and Climatology, 56(9), 2607-2619. https://doi.org/ 10.1175/JAMC-D-16-0332.1

Yuan, R.-M., Deng, Q.-H., Cunningham, D., Xu, C., Xu, X.-W., \& Chang, C.-P. (2013). Density Distribution of Landslides Triggered by the 2008 Wenchuan Earthquake and their Relationships to Peak Ground Acceleration. Bulletin of the Seismological Society of America, 103(4), 2344-2355. https://doi.org/10.1785/0120110233

Zêzere, J. L., Vaz, T., Pereira, S., Oliveira, S. C., Marques, R., \& Garcia, R. A. C. (2015). Rainfall thresholds for landslide activity in Portugal: A state of the art. Environmental Earth Sciences, 73(6), 2917-2936. https://doi.org/10.1007/s12665-014-3672-0 